Duncan, R. A., Backman, J., Peterson, L. C., et al., 1990

Proceedings of the Ocean Drilling Program, Scientific Results, Vol. 115

\title{
43. SITE SURVEY RESULTS FROM THE MASCARENE PLATEAU ${ }^{1}$
}

\author{
M. R. Fisk, ${ }^{2}$ R. A. Duncan,${ }^{2}$ and A. N. Baxter ${ }^{3}$
}

\section{INTRODUCTION}

On 10 March 1987, the Charles Darwin cruise 21/87 departed the Seychelles on a geophysical and geological survey of the Mascarene Plateau and the Rodrigues Ridge (Baxter, 1987). The first 8.5 days of the cruise were spent surveying seven sites that were proposed for drilling during Ocean Drilling Program (ODP) Leg 115. Figure 1 shows the ship's track and the locations of the surveys. The site survey designations and the Leg 115 drilling site numbers are given in Table 1. During Leg 115, Site 707 was drilled close to Site CARB-1, and Sites 705 and 706 were drilled near Site MP-3. Details of the local topography, sediment thickness, and selected single-channel seismic lines are reported here.

\section{SITE SURVEYS}

At each site, gravity, magnetics, $3.5-$ and $10-\mathrm{kHz}$ depth profiles, and single-channel seismic reflection surveys of sediment thickness were obtained. The source for the single-channel seismic reflection was one or more large-chamber air guns (up to 400 in $^{3}$ ). At Site MP-1, a multichannel seismic reflection line was also run using an array of six air guns and a 1-km long streamer of hydrophones.

Satellite navigation was used throughout the cruise. This was accomplished with the Magnavox transit satellite system and was augmented with the global positioning system (GPS) when satellites were available. The ship's track for the surveys of Sites CARB-1, CARB-1A, and MP-3 are shown in the Proceedings of the Ocean Drilling Program, Initial Reports of Leg 115 (Backman, Duncan, et al., 1988), and the ship's track for Sites MP-1 and MP-2 are included here (Figs. 2 and 3, respectively).

At all sites, bathymetric charts and sediment isopach maps were created from the $3.5-\mathrm{kHz}$ echo soundings and from the single-channel seismic reflection records, respectively. Data for all sites are available from the ODP data bank (Lamont-Doherty Geological Observatory of Columbia University).

\section{RESULTS \\ CARB Sites}

Sites CARB-1 and CARB-1A were positioned on top of the thick carbonate platform between the Seychelles Islands and the Saya de Malha Bank. Figure 4 shows the bathymetry in the vicinity of the proposed sites, based on the $3.5-\mathrm{kHz}$ seismic reflection profiles of the Charles Darwin cruise 21/87. Also shown are the location of Site 707 and the subsequent JOIDES Resolu-

\footnotetext{
${ }^{1}$ Duncan, R. A., Backman, J., Peterson, L. C., et al., 1990. Proc. ODP, Sci. Results, 115: College Station, TX (Ocean Drilling Program).

${ }^{2}$ College of Oceanography, Oregon State University, Corvallis, OR 97331, U.S.A.

${ }^{3}$ School of Earth Sciences, Thames Polytechnic, Bigland Street, London E1 2NC, United Kingdom.
}

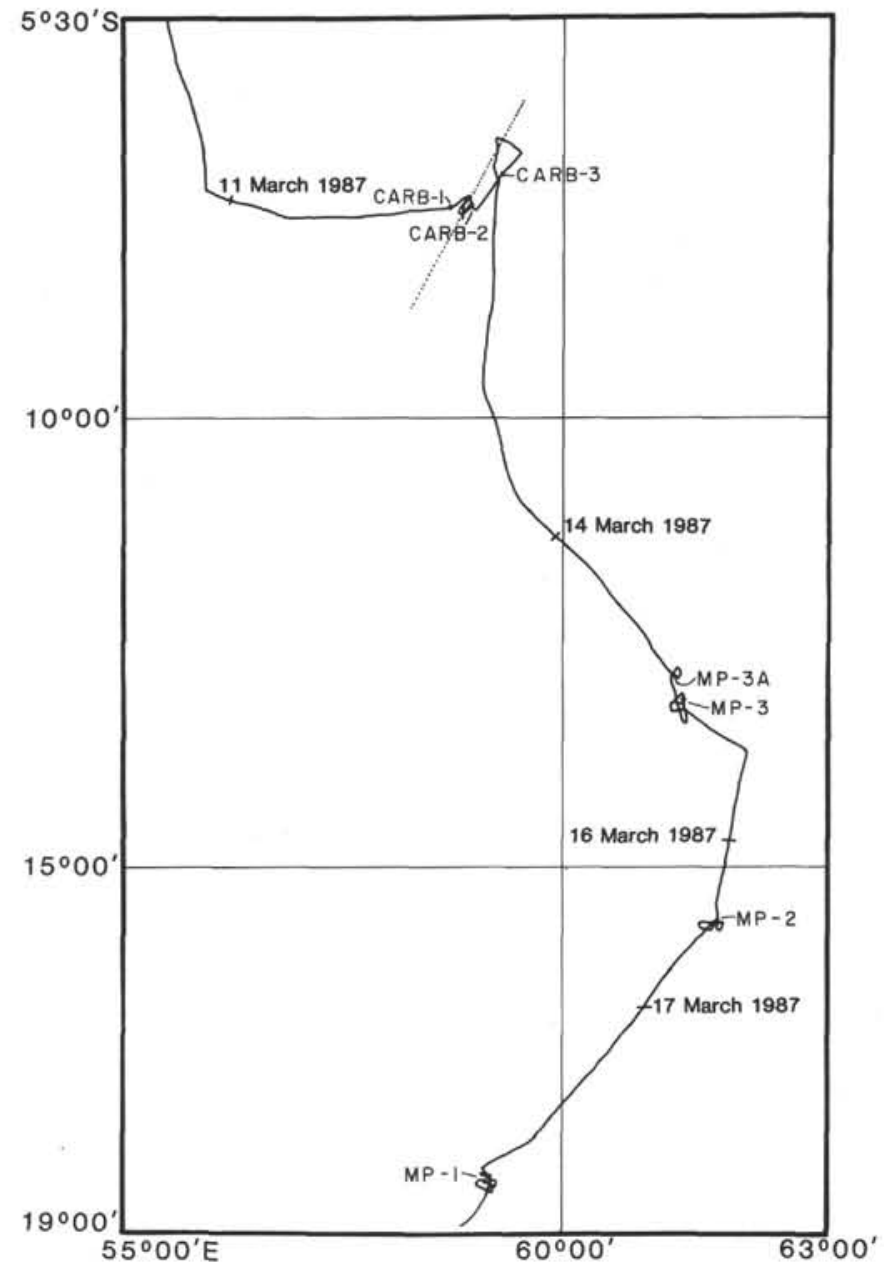

Figure 1. Cruise track for Charles Darwin cruise 21/87. Dates and areas of site surveys are shown along the track. The dotted line is the track of Robert Conrad 1707.

Table 1. Location of surveyed and drilled sites.

\begin{tabular}{lccc}
\hline $\begin{array}{c}\text { Surveyed } \\
\text { sites }\end{array}$ & $\begin{array}{c}\text { Latitude } \\
\left({ }^{\circ} \mathrm{S}\right)\end{array}$ & $\begin{array}{c}\text { Longitude } \\
\left({ }^{\circ} \mathrm{E}\right)\end{array}$ & $\begin{array}{c}\text { Leg 115 } \\
\text { drilling } \\
\text { sites }\end{array}$ \\
\hline CARB-1A & $7^{\circ} 37^{\prime}$ & $58^{\circ} 47^{\prime}$ & \\
CARB-1 & $7^{\circ} 36^{\prime}$ & $58^{\circ} 58^{\prime}$ & 707 \\
CARB-2 & $7^{\circ} 16^{\prime}$ & $59^{\circ} 18^{\prime}$ & \\
MP-3 & $13^{\circ} 10^{\prime}$ & $61^{\circ} 23^{\prime}$ & $705 / 706$ \\
MP-3A & $12^{\circ} 54^{\prime}$ & $61^{\circ} 17^{\prime}$ & \\
MP-2 & $15^{\circ} 36^{\prime}$ & $61^{\circ} 46^{\prime}$ & \\
MP-1 & $18^{\circ} 25^{\prime}$ & $59^{\circ} 09^{\prime}$ & \\
\hline
\end{tabular}




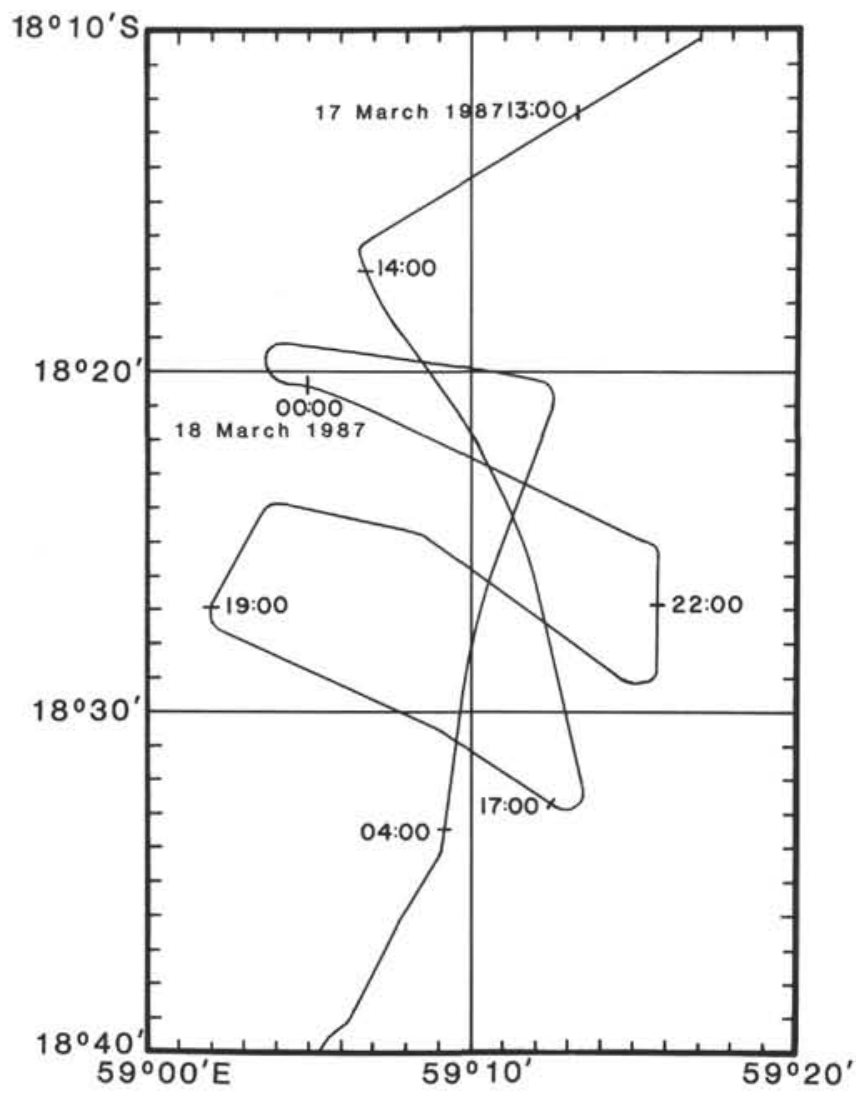

Figure 2. Ship's track for the survey of proposed drill Site MP-1. Dates and time marks (GMT) are given along the track line. The location of the multichannel seismic reflection line (D21/87) through this area is shown in Figure 11.

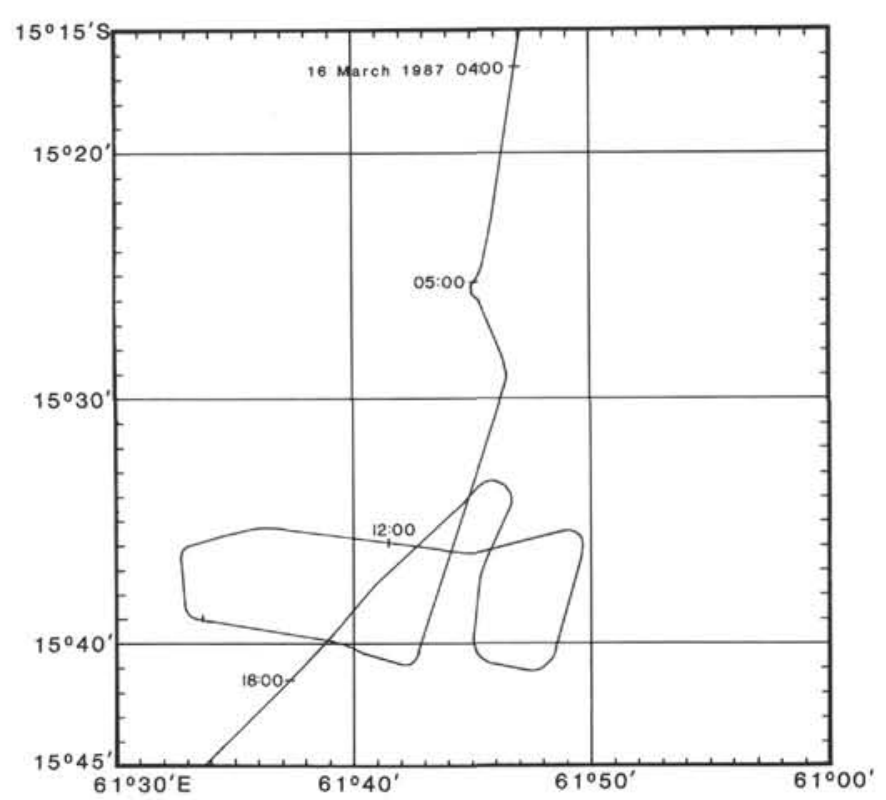

Figure 3. Ship's track for the survey of proposed drill Site MP-2. Date and time marks (GMT) are given along the track line.

tion line through the survey area. The seafloor lies between $1400-$ and $1650-\mathrm{m}$ water depth and dips to the north.

The track of Robert Conrad 1707 is indicated with a dashed line, and the seismic reflection profile from that track is shown in Figure 5. The Leg 115 seismic profiles are given in the "Underway Geophysics" chapter in Backman, Duncan, et al. (1988). A sediment isopach map for the area around Sites CARB-1 and CARB-1A was constructed from the Charles Darwin singlechannel seismic data (Fig. 6). Sediment thickness is given in two-way traveltime (twt) in seconds. The sediment is generally $0.2-0.4 \mathrm{~s}$ thick, and Site 707 appears to be in a region where the sediment thickness is $0.4 \mathrm{~s}$, based on the JOIDES Resolution seismic reflection line (Backman, Duncan, et al., 1988). This corresponds to the $385-\mathrm{m}$ drilled sediment section at this site.

\section{Site MP-3}

The ship's track and the bathymetry of Site MP-3 are given in Backman, Duncan, et al. (1988), and the water depth here is 1500-2500 m. The sediment isopach map based on the Charles Darwin survey (Fig. 7) shows that the sediment is as much as $0.4 \mathrm{~s}$ thick. However, several east-west channels cut through the sediment, and in places it is $<0.1 \mathrm{~s}$ thick.

The dashed line in Figure 7 shows the position of the JOIDES Resolution seismic reflection line that was run up to Site 705 (Backman, Duncan, et al., 1988). An additional seismic reflection line from the Charles Darwin survey that is parallel to the Leg 115 track is shown in Figure 8. In this profile the valleys and intermediate highs stand out. Site 705 was located on a high (10 km east of time mark 2330 in Fig. 8), and Site 706 was situated on the south side of an east-west valley similar to that shown between time marks 2200 and 2300 .

\section{Site MP-2}

Site MP-2 was proposed for drilling because its location suiggested that it was intermediate in age between that of Mauritius and Sites MP-3 and CARB-1. Site MP-2 lies on the eastern flank of the Mascarene Plateau in water depths of 1700-2800 m where the carbonate cap was thin enough to be penetrated with a single rotary drilling bit. The bathymetry and the sediment thickness at the site are given in Figures 9 and 10, respectively. In the shallower water at the western edge of the site, the sediment reaches its greatest thickness $(0.8 \mathrm{~s})$, but in deeper water to the east, the sediment appears to disappear completely.

\section{Site MP-1}

This site is located in a basin between the eastern end of the Rodrigues Ridge and the Mascarene Plateau. Water depth at this site is $2,400-2,800 \mathrm{~m}$, but it shoals rapidly to the east onto the Rodrigues Ridge and to the west onto a seamount (Fig. 11). Two dredges to the east of Site MP-1 recovered basalt, carbonate, and manganese nodules, but the one dredge within the survey area (RR13A) recovered only lithified carbonate and manganese nodules. Three piston cores to the west of Site MP-1 recovered 3-4 $\mathrm{m}$ each of carbonate ooze, and one pilot core also recovered $1 \mathrm{~m}$ of carbonate sediment. Sediment thickness at this site was $0.15-0.25$-s twt and appeared to thin toward the Rodrigues Ridge and the Mascarene Plateau (Fig. 12).

\section{REFERENCES}

Backman, J., Duncan, R. A., et al., 1988. Proc. ODP, Init. Repts., 115: College Station, TX (Ocean Drilling Program).

Baxter, A. N., 1987. Cruise Report, RRS Charles Darwin 21/87: Barry, U.K. (Natural Environmental Research Council, Research Vessel Services).

Carter, J.J.D., 1980. Echo-Sounding Correction Tables (3rd ed.): Tauntor-Sommerset, U.K. (Hydrographic Department of the Ministry of Defence).

Date of initial receipt: 25 September 1989

Date of acceptance: 2 January 1990

Ms 115B-120 


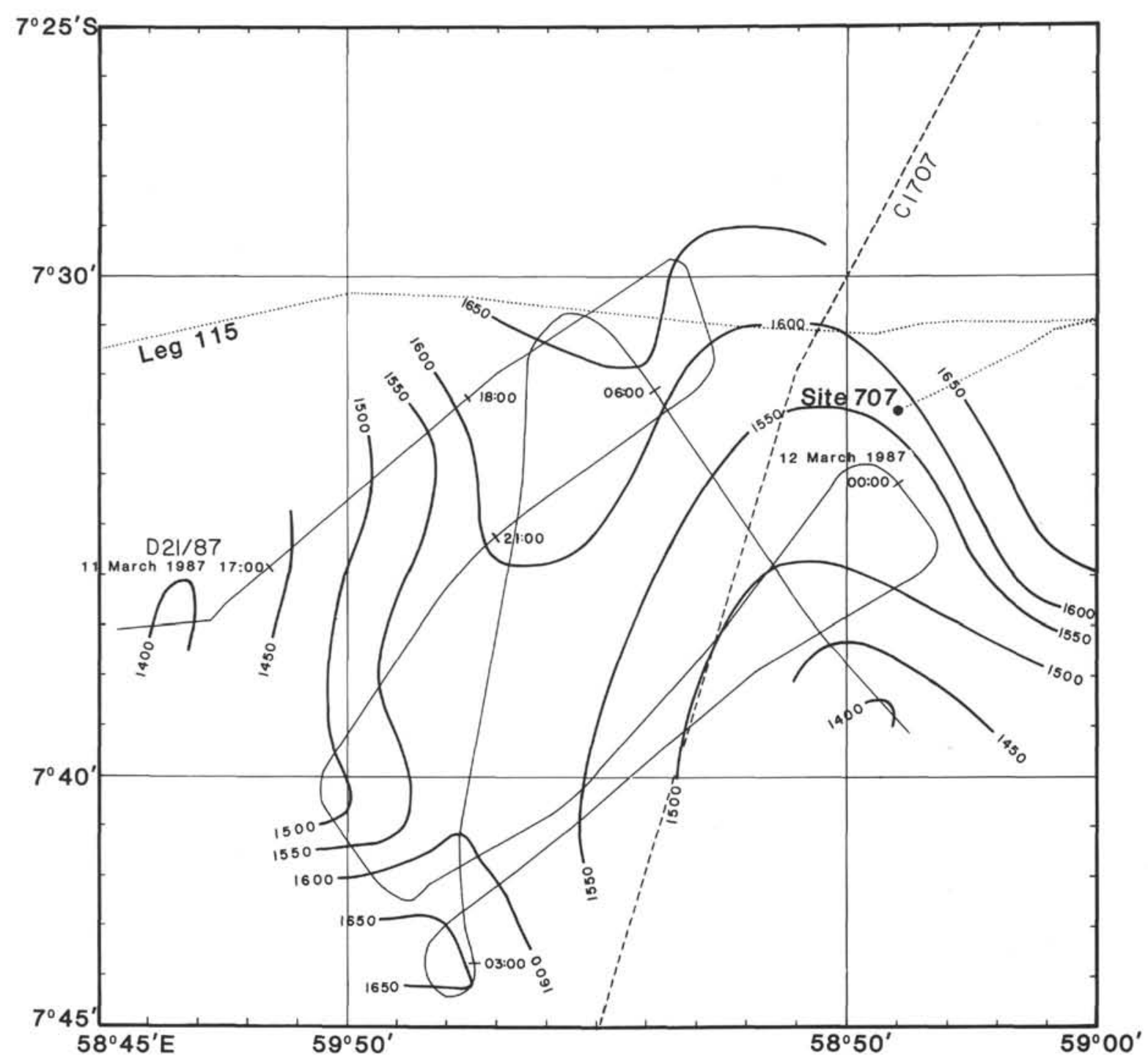

Figure 4. Bathymetric chart in corrected meters (Carter's Tables; Carter, 1980) for proposed drill Site CARB-1. Contour interval $=50 \mathrm{~m}$. The location of the seismic line for Robert Conrad $1707(\mathrm{C} 1707)$ is indicated with a dashed line. The locations of Site 707 and the JOIDES Resolution seismic line for Leg 115 are also shown. Date and time marks (GMT) are given along the Charles Darwin survey line (D21/87). 


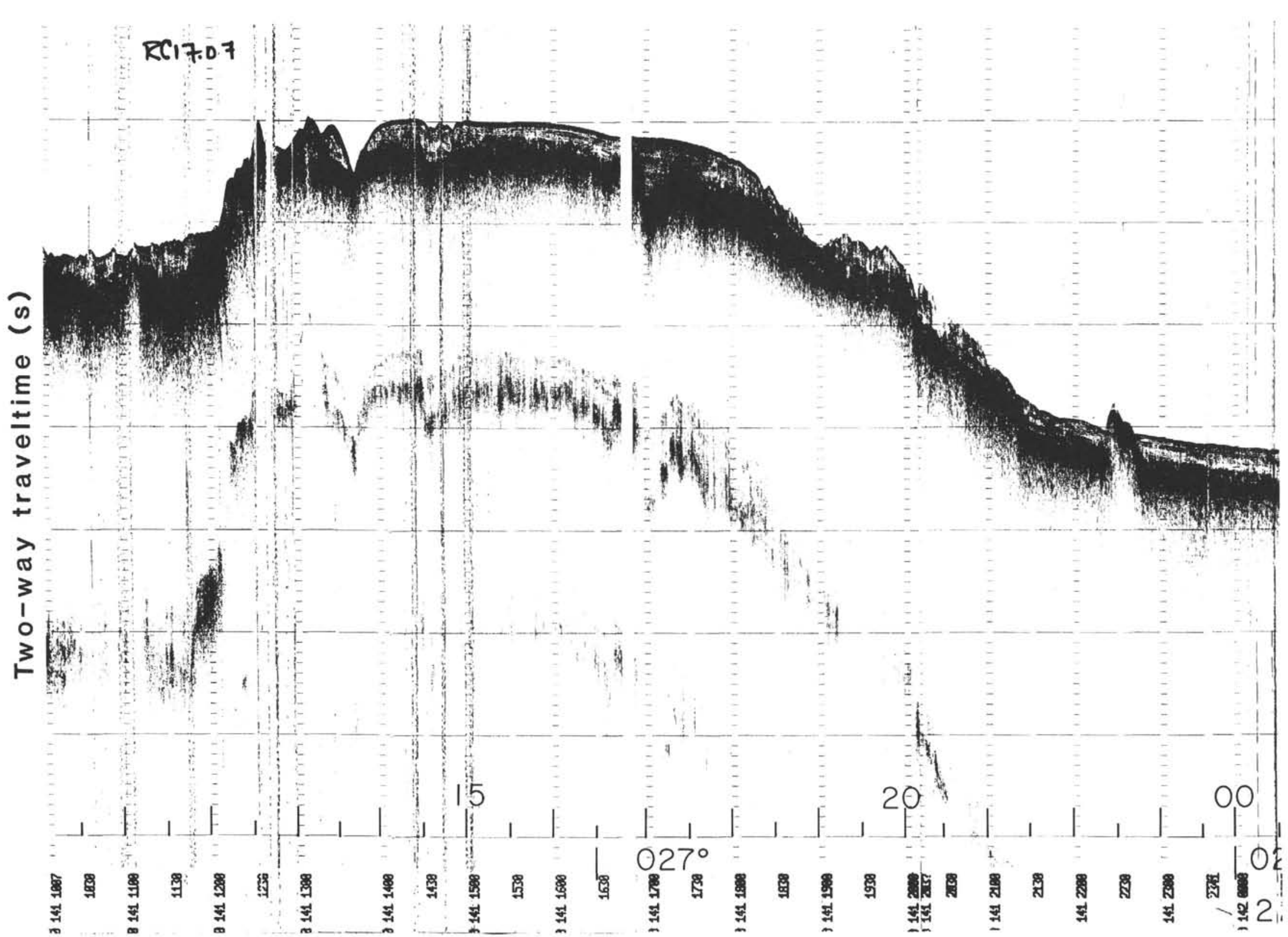

Figure 5. Single-channel seismic reflection line for Robert Conrad cruise 1707 across the Mascarene Plateau and crossing the area where Site 707 was drilled. The segment of the line that is shown in Figure 4 extends from time mark 1500 to 1730 . Seismic reflection time marks are at 1-s (two-way traveltime) intervals. 


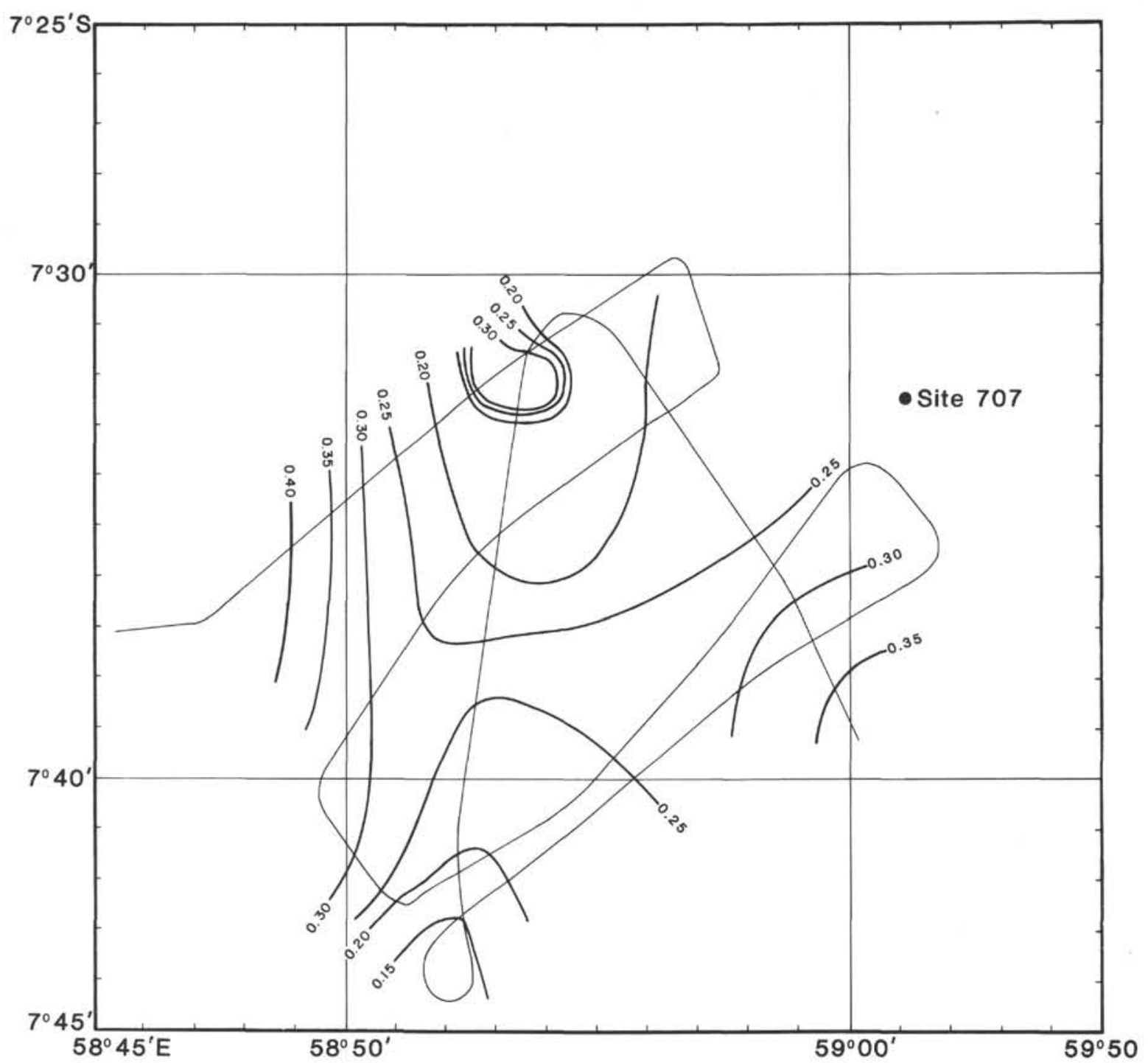

Figure 6. Sediment isopach map for Site CARB-1 with contours in seconds (twt) based on the Charles Darwin 21/87 seismic reflection survey. The location of Site 707 is shown. 


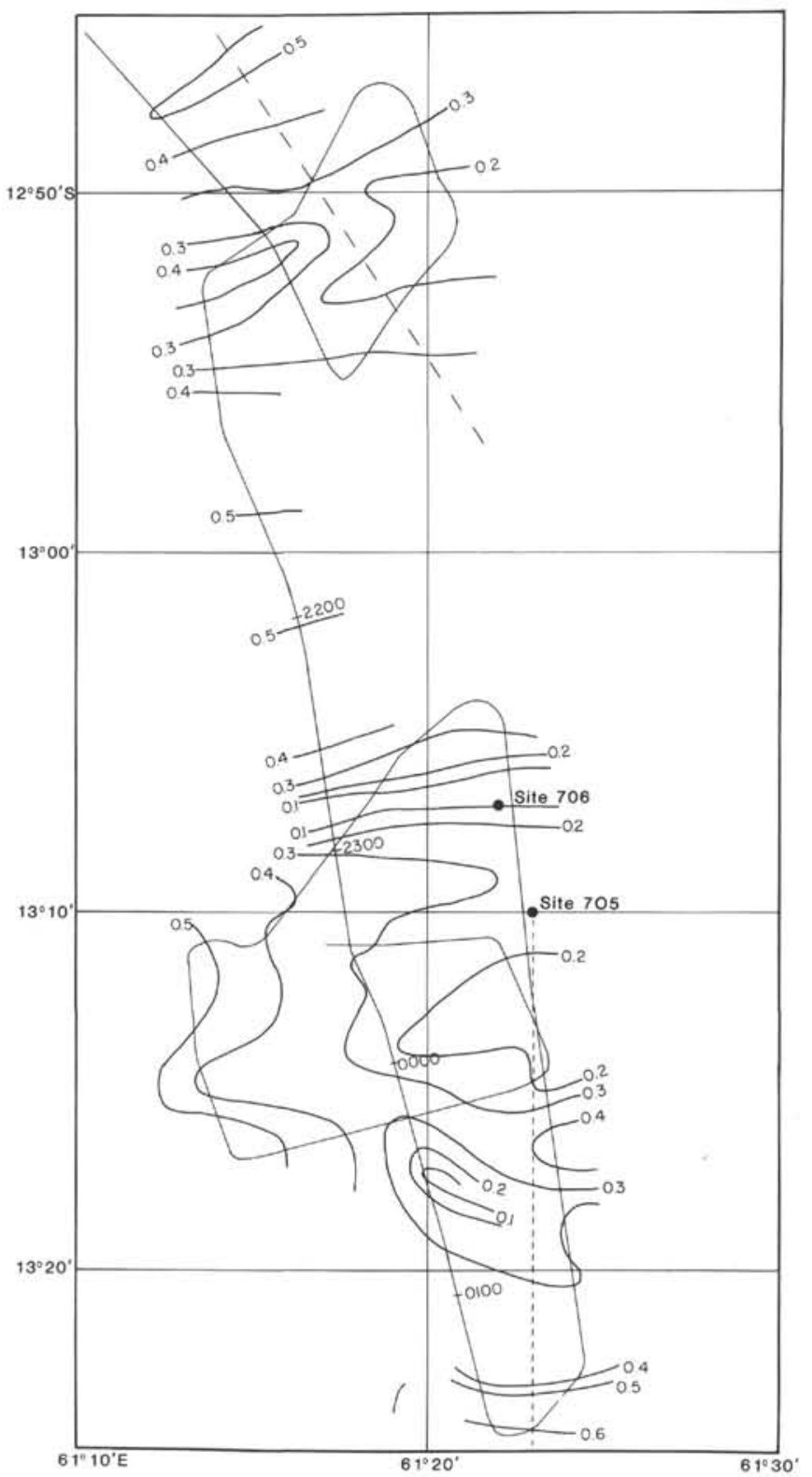

Figure 7. Sediment isopach map for the area of Site MP-3. The contour interval is in seconds (twt). The dashed line is the track of JOIDES Resolution. Sites 705 and 706 are also indicated. Time marks (GMT) are given along the Charles Darwin 21/87 track. 


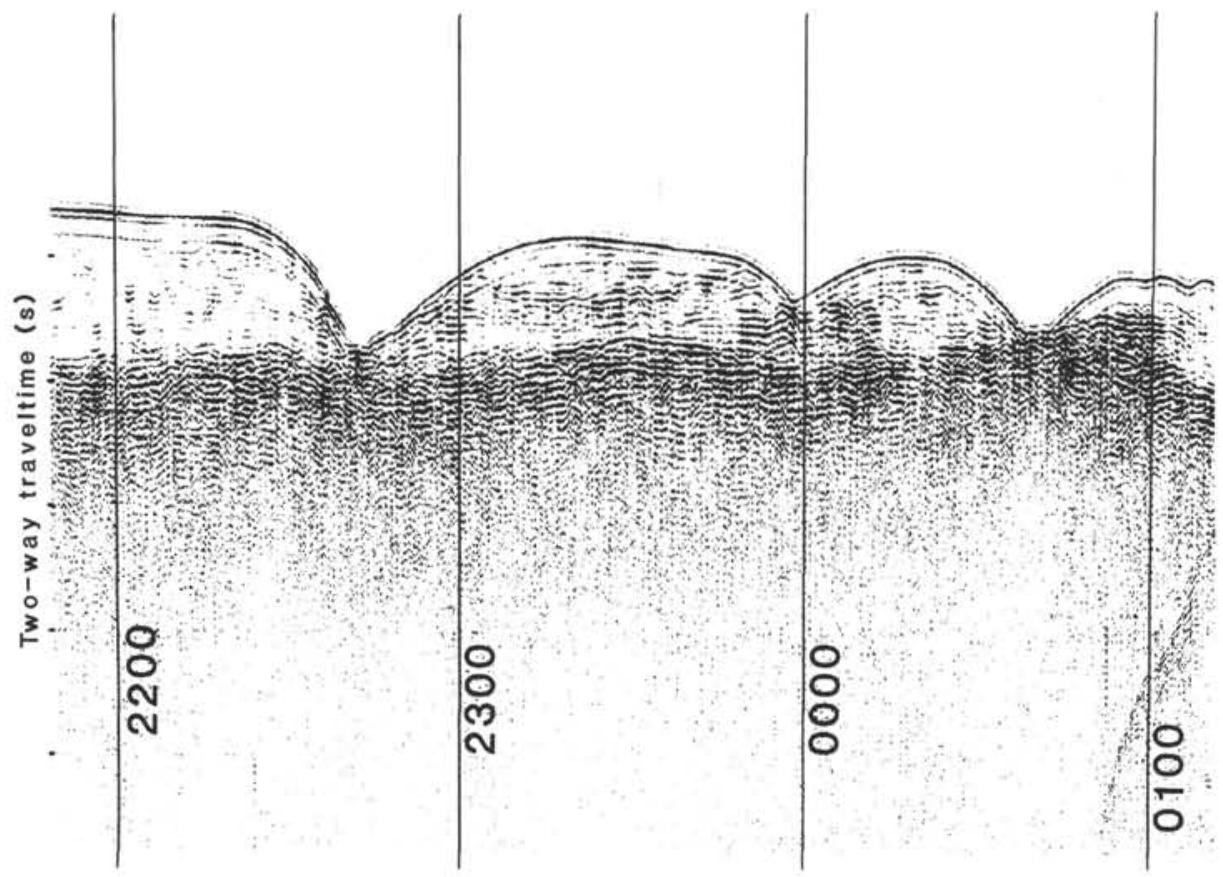

Figure 8. Single-channel seismic line from the Charles Darwin survey for Site MP-3. Additional seismic lines from Leg 115 are given in Backman, Duncan, et al. (1988). Times correspond to times along the ship's track in Figure 7. Time marks are given in 0.2-s (two-way traveltime) intervals.

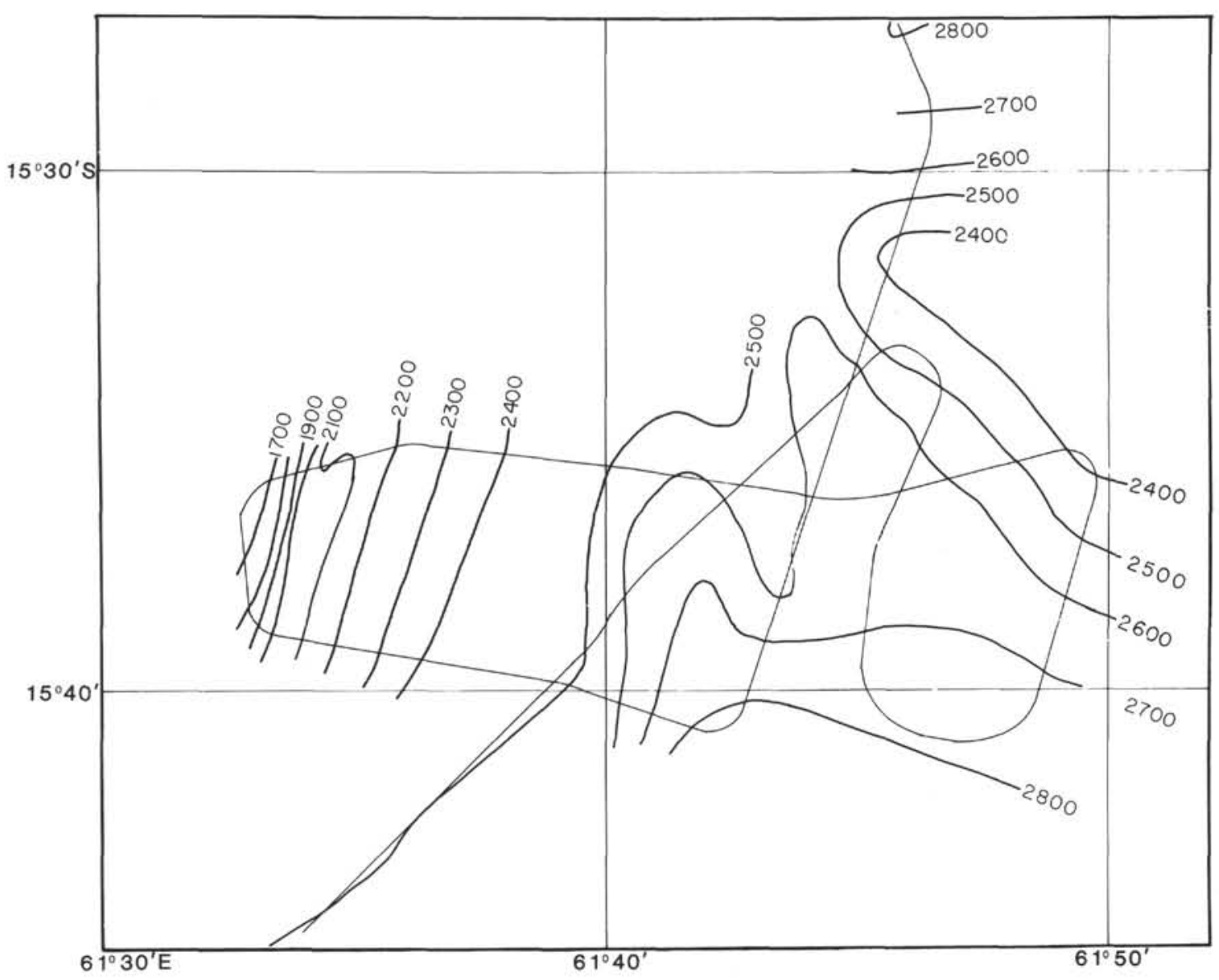

Figure 9. Bathymetric chart of Site MP-2, contoured in corrected meters (Carter's Tables; Carter, 1980). 
DATA REPORT—_

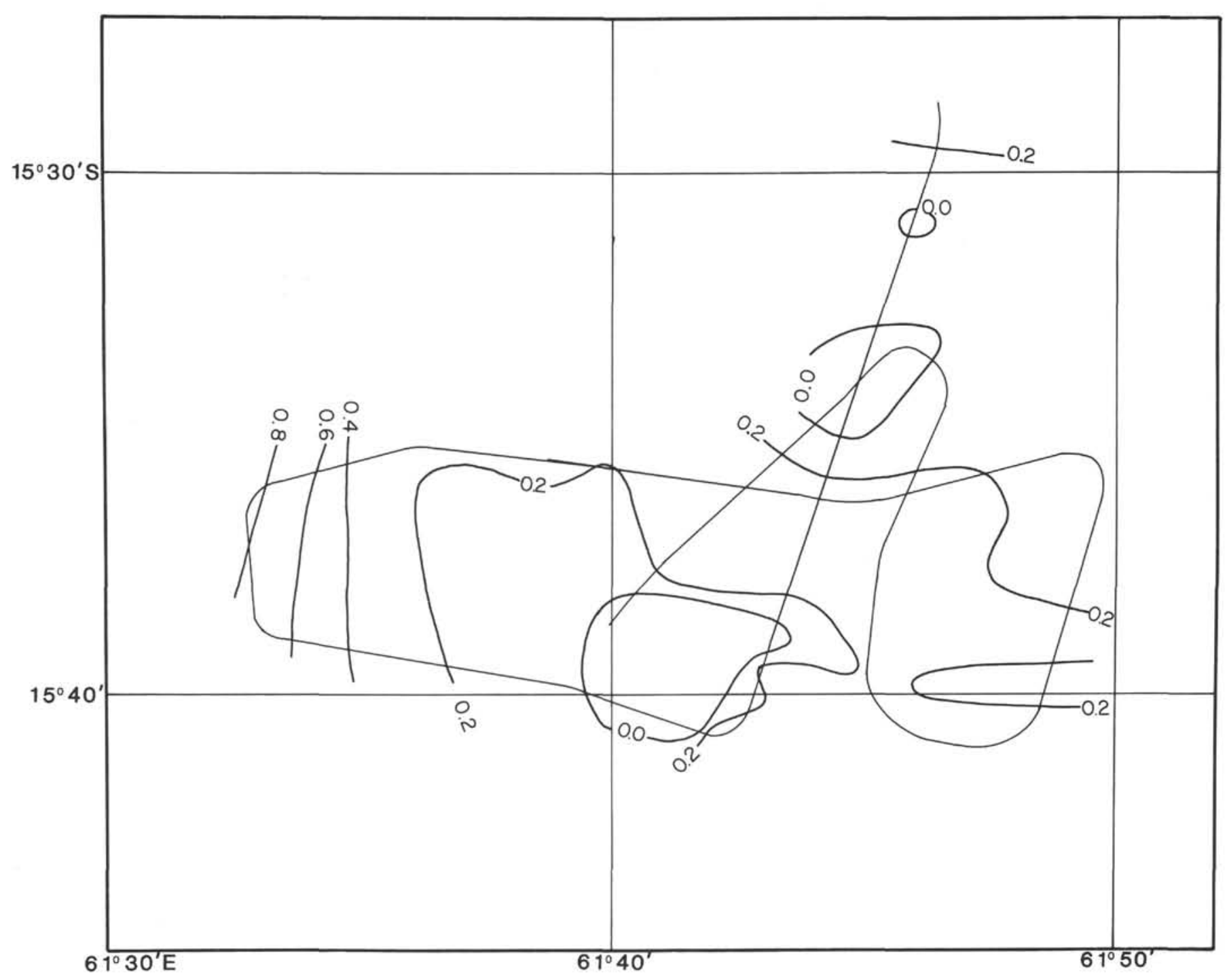

Figure 10. Sediment thickness in two-way traveltime at Site MP-2.

788 


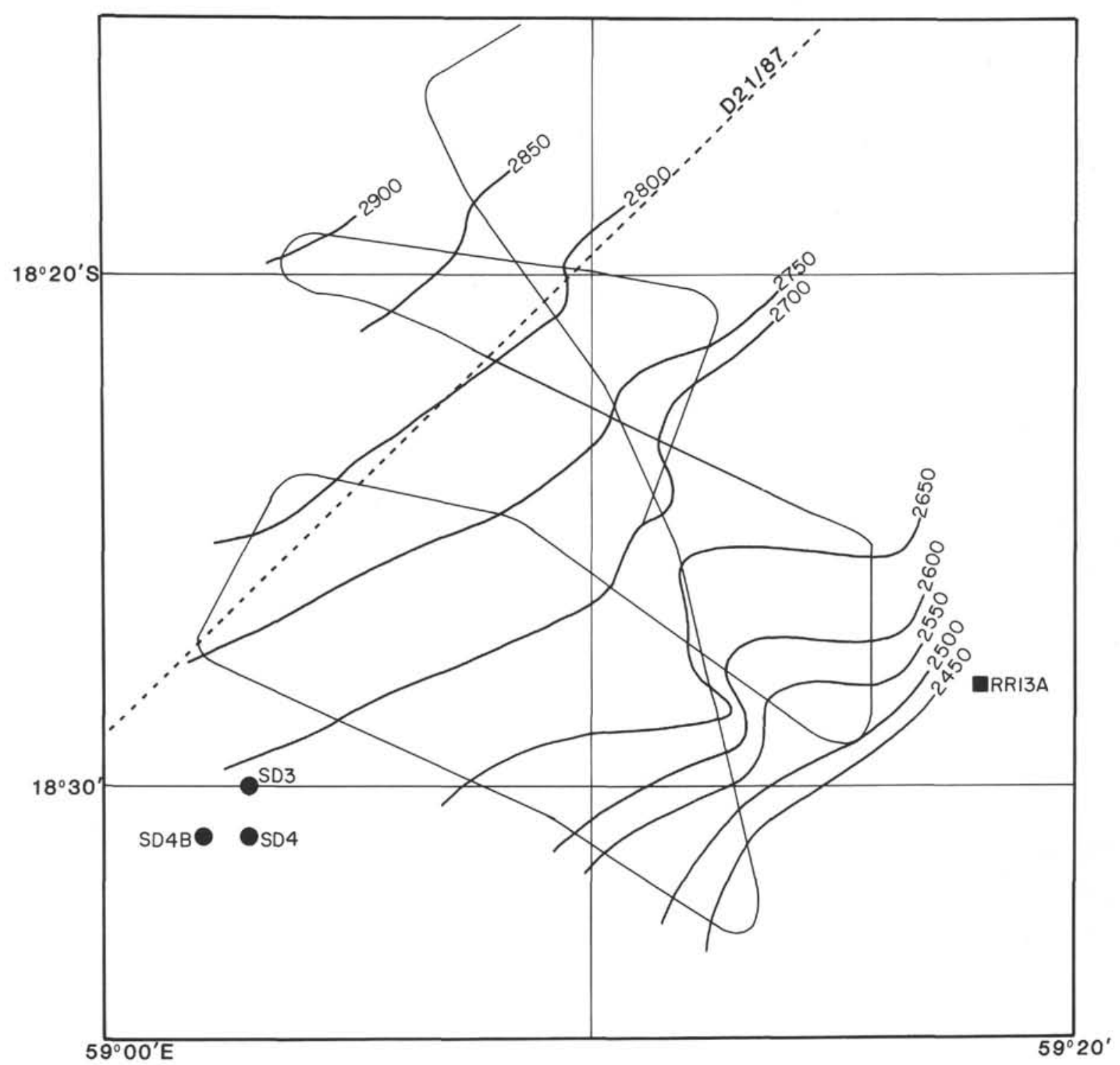

Figure 11. Area of Site MP-1 showing water depth in corrected meters (Carter's Tables; Carter, 1980). The sites of dredged carbonates and manganese nodules (RR13A; filled square) and of three piston cores that recovered carbonates (SD3, SD4, and SD4B; filled circles) are also shown. The dashed line is the location of a multichannel seismic line made across the site by Charles Darwin cruise $21 / 87$. 
DATA REPORT —_

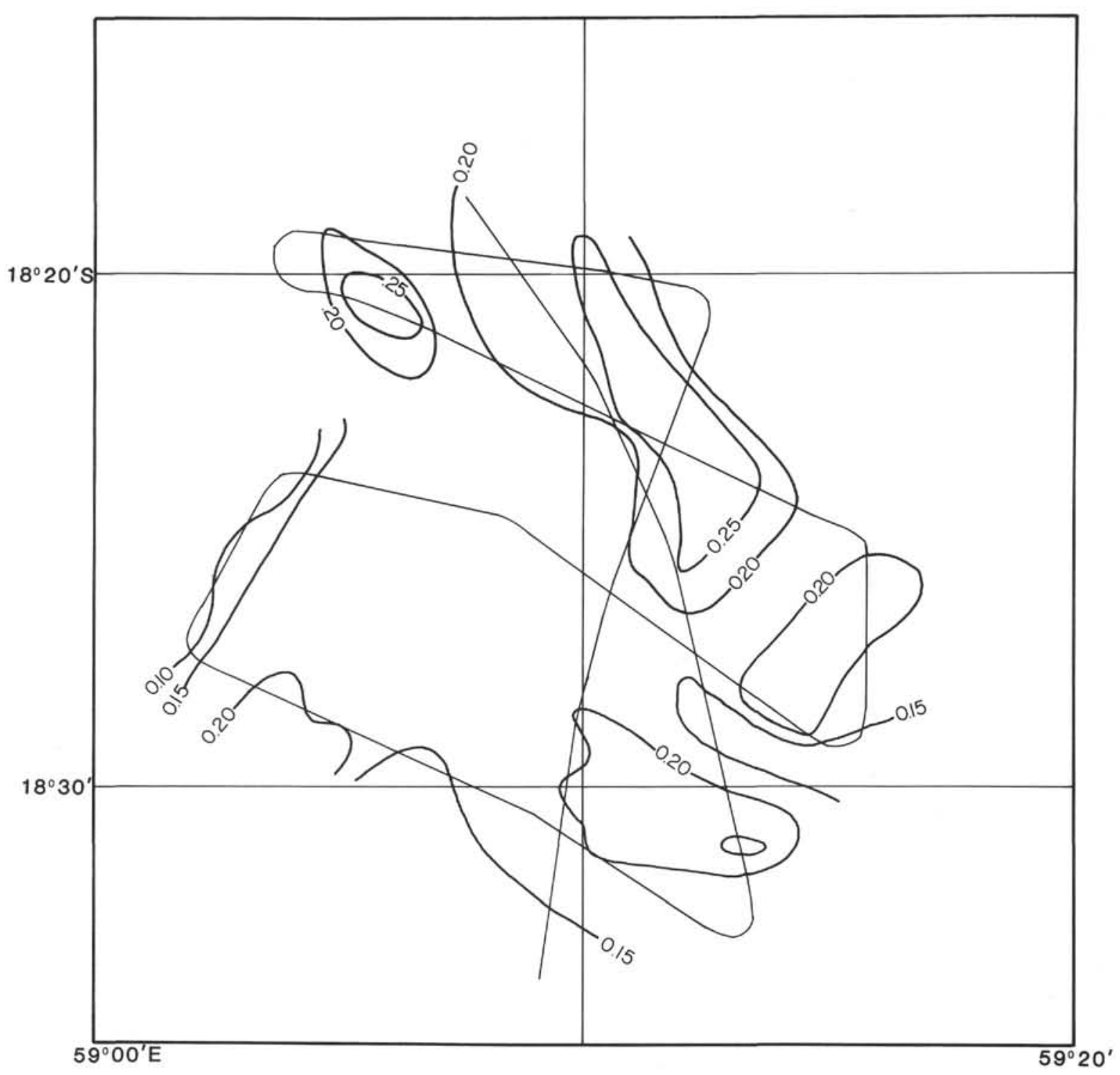

Figure 12. Sediment thickness in two-way traveltime for Site MP-1. Sediment varies in thickness from 0.1 to $0.25 \mathrm{~s}$.

790 